\title{
Strategi Guru Dalam Pembelajaran Pendidikan Agama Islam Terhadap Anak Berkebutuhan Khusus (Tunagrahita Sedang) Di SDLB Negeri Pangkalpinang
}

\author{
Soleha $^{1}$, Erika Setia Ningsih ${ }^{2}$, Siska Dwi Paramitha ${ }^{3}$ \\ ${ }^{1}$ IAIN Syaikh Abdurrahman Siddik Bangka Belitung \\ ${ }^{2}$ IAIN Syaikh Abdurrahman Siddik Bangka Belitung \\ ${ }^{3}$ IAIN Syaikh Abdurrahman Siddik Bangka Belitung
}

Info Artikel :

Diterima 12 April 2020

Direvisi 20 April 2020

Dipublikasikan 27 April 2020

\section{Kata Kunci:}

Strategi pembelajaran, Pendidikan Agama Islam, Anak Tunagrahita sedang.

\section{Keywords:}

Strategies in Teaching Learning,

Islamic studies,

Ward Difable Students

\begin{abstract}
ABSTRAK
Fokus penelitian ini berkenan dengan strategi guru dalam pembelajaran Pendidikan Agama Islam terhadap Anak Tunagrahita Sedang di SLB Pangkalpinang. Dengan tujuan untuk mendeskripsikan tentang strategi guru PAI dalam proses pembelajaran dan kendala yang dihadapinnya. Jenis penelitian ini menggunakan penelitian kulitatif deskriptif dengan metode pengumpulan data melalui wawancara, observasi, dokumentasi, untuk jawaban dari rumusan masalah. Adapun hasil penelitiannya yaitu strategi yang digunakan guru dalam pembelajaran Pendidikan Agama Islam bagi Anak Tunagrahita Sedang di SLBN pangkalpinang yaitu Active Learning, Contextual Teacing Learning (CTL), Cooperative Learning, dan PAIKEM. Namun yang sering digunakan adalah Active Learning, Contextual Teacing Learning (CTL). Adapun kendala yang dihadapi guru dalam proses pembelajaran Pendidikan Agama Islam terdiri dari faktor internal dan eksternal. Faktor internal terdiri dari profesionalitas guru dalam berinteraksi terhadap Anak Tunagrahita Sedang. Kedua, faktor eksternal yang terdiri dari kondisi peserta didik dan fasilitas yang berada disekolah.
\end{abstract}

\section{ABSTRACT}

The focus of this research deals with the teachers strategies in teacher learning of Islamic Studies to ward studies with Middle Mental Retardation of State Difable Elementary School Pangkalpinang. The objective is to discribe the strategies of Islamic Studies Teacher in teaching learning process and the problem on it. This research applied qualitative descriptive, the method of collecting data by interview, observation, documentation to answer the research problems. The result of the research is that the strategies used by the teachers in teaching learning Islamic Studies of Middle Mental Retardation in State Difable Elementary school Pangkalpinang are active Learning, Contextual, Teaching Learning, Cooperative Lerning, and PAIKEM ( is the Indonesia Shorten Term of Active, Inovative, Creative, Effective, and Fun Teaching Learning. But commonly used the Active Learning and Contextual Teaching Learning. The problem faces by teachers in the teaching learning of Islamic Studies consists of Internal and External factors. Internal factor is the teachers profesionalism in interacting with the students with Middle Mental Retardation. The second, eksternal factors is the students conditions and the school facilities.

\section{Koresponden:}

Soleha

Soleha215x@gmail.com 


\section{Pendahuluan}

Pendidikan merupakan hak dan kewajiban bagi setiap individu untuk memanfaatkan maupun menggali semua potensi yang dimilikinya. Pendidikan dilakukan agar seseorang memperoleh pemahaman tentang suatu ilmu. Selain itu, pendidikan juga dapat mempermudah seseorang menyesuaikan diri dengan lingkungan sekitarnya. Maka, pendidikan merupakan hal yang sangat penting bagi kehidu

pan manusia. Sekolah Anak Berkebutuhan Khusus (ABK) adalah sekolah-sekolah yang diselenggarakan khusus untuk mendidik ABK. Sekolah ini disebut sebagai SLB (Sekolah Luar Biasa) dan diselenggarakan baik oleh pemerintah maupun oleh swasta. Penyelenggaraan sekolah/pendidikan untuk ABK ini didasarkan pada implementasi pasal 32 (1) UU No. 20 Tahun 2003 yang menyatakan bahwa pendidikan khusus merupakan pendidikan bagi peserta didik yang memiliki tingkat kesulitan dalam mengikuti proses pembelajaran karena kelainan fisik, emosional, mental, sosial, atau memiliki potensi kecerdasan dan bakat istimewa (Murtie, 2016)

ABK merupakan istilah lain untuk menggantikan kata "Anak Luar Biasa (ALB)" yang menandakan adanya kelainan khusus. ABK dapat diartikan sebagai anak-anak yang memiliki karakteristik berbeda, baik secara fisik, emosi, ataupun mental dengan anak-anak lain seusianya. (Delphie, 2006) Untuk mencapai proses pembelajaran dapat berjalan efektif dan efisien, maka penguasaan materi saja tidak cukup. Namun, pendidik juga harus memiliki strategi pembelajaran sendiri yang sesuai dengan kemampuan peserta didik, apalagi di Sekolah Luar Biasa terdapat berbagai macam anak yang memiliki keterbatasan tertentu. Namun tetap memberikan layanan pendidikan, agar setiap peserta didik menjadi individu yang mandiri, beriman, dan bertaqwa kepada Tuhan yang Maha Esa, berbudi luhur, terampil, dan mampu berperan sosial.

Anak dengan kebutuhan khusus berdasarkan jenis-jenisnya terbagi menjadi 2 karakteristik. Anak dengan karakteristik fisik yang berbeda yakni: Tunadaksa, Tunanetra, Tunarungu, Tunawicara. Sedangkan anak dengan karakteristik psikis yang berbeda yakni: Tunagrahita, Lambat belajar, Autis, ADHD, Gifted, Jenius, dan Tunalaras. (Murtie, 2016). Bagi anak berkebutuhan khusus, pendidikan sangat berarti karena memberi landasan yang kuat bahwa anak Tunagrahita sedang perlu memperoleh kesempatan sama sebagaimana yang diberikan kepada anak normal lainnya dalam hal pendidikan dan pengajaran.

Memberikan kesempatan yang sama kepada Anak Tunagrahita Sedang untuk memperoleh pendidikan dan pengajaran, berarti memperkecil kesenjangan angka partisipasi pendidikan anak normal dengan Anak Tunagrahita Sedang. Oleh sebab itu, peran guru sangat penting dalam mendidik Anak Tunagrahita Sedang. Karena Anak Tunagrahita Sedang tidak bisa menangkap dan memahami materi pelajaran yang disampaikan oleh guru dengan cepat.

Anak Tunagrahita Sedang, merupakan istilah yang digunakan untuk menyebut anak atau orang yang memiliki kemampuan intelektual di bawah rata-rata atau bisa juga disebut dengan retardasi mental (Aqila, 2010). Seseorang dikategorikan berkelainan mental subnormal atau Tunagrahita, jika ia memiliki tingkat kecerdasan yang sedemikian rendahnya (IQ 80-terendah). Sedangkan untuk Anak Tunagrahita Sedang meiliki IQ 50-30. Sehingga untuk melakukan tugas perkembangannya memerlukan bantuan dan bimbingan atau layanan secara spesifik, termasuk dalam program pendidikan dan pengajarannya. Perlu dipahami bahwa, kondisi Anak Tunagrahita Sedang tidak dapat disamakan dengan penyakit, atau berhubungan dengan penyakit, tetapi keadaan Tunagrahita suatu kondisi sebagaimana yang ada (Efendi,2005). Atas dasar itulah, Tunagrahita dalam gradasi manapun tidak bisa disembuhkan atau diobati dengan obat apa pun.

Pandangan ini memberikan pemahaman bahwa, Anak Tunagrahita Sedang akan berpeluang besar dalam meraih kesuksesan hidup jika mampu mengembangkan kecerdasan lain di luar IQ. Adapun kecerdasan lain di luar IQ yaitu: bakat, hubungan sosial, kematangan emosional, kecerdasan spiritual, dan banyak hal yang harus bisa di optimalkan dari Anak Tunagrahita Sedang. Untuk mewujudkan semua itu, kerja sama guru dan orang tua perlu dibangun dengan baik dan kuat, agar dapat memberikan kesempatan bagi Anak Tunagrahita Sedang dalam mengoptimalkan kecerdasannya.

Layanan pendidikan yang diberikan kepada Anak Tunagrahita Sedang harus relevan dengan kebutuhan dan kondisi mereka. Guru perlu memahami Anak Tunagrahita Sedang, baik dari jenis, karakteristik, etiologi penyebab kelainan, dampak psikologis serta prinsip-prinsip layanan pendidikan. Hal ini dimaksudkan agar guru memiliki wawasan yang tepat tentang keberadaan Anak Tunagrahita Sedang, sebagai sosok individu masih berpotensi dapat terlayani secara maksimal. Untuk itu, setiap satuan pendidikan jalur pendidikan di sekolah harus menyediakan sarana belajar yang sesuai dengan kurikulum 
sekolah. Proses kegiatan pembelajaran harus mampu menyentuh semua aspek perkembangan perilaku dan kebutuhan setiap Anak Tunagrhita Sedang.

Menurut Komar, dalam memberikan pelajaran kepada Anak Tunagrahita Sedang, materi yang akan disampaikan akan lebih menarik jika mengaitkan materi tersebut ke isu-isu yang sekarang terjadi (baik masalah penyakit, kondisi alam, trnsportasi dll). Dengan pola pembelajaran seperti itu, akan mempermudah Anak Tunagrahita Sedang dalam memahami pelajaran.

Untuk itu, setiap guru harus mempunyai strategi dalam menyampaikan materi pembelajaran dengan memperhatikan kondisi anak yang berbeda dari anak pada umumnya. Sehingga pendidik harus memiliki pengetahuan, skill yang baik untuk menentukan strategi pembelajaran bagi Anak Tunagrahita Sedang, khususnya guru Pendidikan Agama Islam yang berada di SDLB Negeri Pangkalpinang.

Berdasarkan uraian di atas, maka masalah yang akan dibahas pada penelitian ini, yaitu: Bagaimana strategi guru agama Islam dalam menanamkan Pendidikan Agama Islam kepada Anak Berkebutuhan Khusus (Tunagrahita Sedang) di SDLB Negeri Pangkalpinang dan Apa saja kendala guru Agama Islam dalam penanaman Pendidikan Agama Islam kepada Anak Berkebutuhan Khusus (Tunagrahita Sedang) di SDLB Negeri Pangkalpinang

\section{Metode}

Jenis Penelitian ini adalah kualitatif dengan metode deskriptif. Dengan tujuan untuk menggambarkan dan menarik interpretasi dari data dan informasi yang diperoleh dalam menjawab permasalahan pada penelitian ini. Penelitian ini dilakukan di SDLB Negeri Pangkalpinang.

Teknik pengumpulan data yaitu dengan cara observasi, yakni melakukan pengamatan dengan turun langsung ke lapangan. Wawancara mendalam dapat dilakukan berkali-kali sehingga diperoleh jawaban yang relevan terkait masalah penelitian. Selanjutnya studi dokementasi, yakni berupa dokumen tertulis dalam bentuk buku, Undang-Undang, Peraturan Pemerintah, internet, dan lain sebagainya yang mendukung informasi yang diperlukan pada penelitian ini.

Sedangkan teknik penentuan informan pada penelitian ini terdiri dari informan kunci yaitu guru pendidikan agama Islam SDLB Negeri Pangkalpinang. Sedangkan informan pendukung yakni staf administrasi yang melaksanakan teknis-teknis dilapangan terkait dengan dokumentasi dan data pendukung lainnya.

\section{Hasil dan Pembahasan}

Pembahasan ini akan mejelaskan tentang hasil temuan di lapangan dan menjawab dari rumusan masalah. SLB (Sekolah Luar Biasa) Negeri Pangkalpinang, salah satu bentuk penyelenggaraan PLB (Pendidikan Luar Biasa) yang berdiri pada tahun 1983. Meskipun di kabupaten lainnya terdapat SLB namun, untuk center difokuskan di SLB Pangkalpinang. Mengingat lokasi SLB ini berada di ibukota Provinsi Kepulauan Bangka Belitung. SLB berdiri berdasarkan peraturan pada waktu itu, Undang-Undang RI No. 20 Tahun 1989 tentang SISDIKNAS, Peraturan Pemerintah RI No. 72 Tahun 1981 tentang Pendidikan Luar Biasa, Keputusan Menteri P dan K No. 002/U 1986 tentang Pendidikan Luar Biasa.

Pendirian dari SLBN Pangkalpinang memiliki visi dan misi yaitu:

Visi: "menjadikan peserta didik yang beriman, bertaqwa, mandiri, terampil, peduli sosial, hidup bersih dan cinta lingkungan".

Misi:

1) Memberikan penyuluhan dan memfasilitasi kegiatan-kegiatan keagamaan;

2) Memberikan pelayanan yang prima sesuai dengtan kebutuhan dan kemampuan anak didik;

3) Meninngkatkan mutu pendidikan Luar Biasa;

4) Menanamkan dan menumbuhkan kemandirian dengan membekali life Skill sesuai kemampuan peserta didik.

Strategi Pembelajaran Bagi Anak berkebutuhan Khusus (Tunagrahita Sedang) di SDLB Negeri Pangkalpinang. 
Strategi merupakan salah satu faktor penting dalam proses pembelajaran. Menurut Majid, strategi adalah suatu kegiatan pembelajaran yang harus dikerjakan guru dan peserta didik agar tujuan pembelajaran dapat dicapai secara efektif dan efisien(Majid, 2012). Walaupun pada awalnya, istilah strategi menurut Wina digunakan dalam dunia militer yang diartikan sebagai cara penggunaan seluruh kekuatan militer untuk memenangkan suatu peperangan. (Sanjaya, 2010). Dalam dunia pendidikan J.R. David menyebutkan strategi diartikan sebagai a plan, method, or series of activities designed to achieves a particular educational goal. Sehingga dapat disebutkan bahwa strategi pembelajaran merupakan suatu kegiatan pembelajaran yang harus dikerjakan guru dan peserta didik agar tujuan pembelajaran dapat tercapai secara efektif dan efesien.

Pengertian tersebut juga dipahami oleh guru Pendidikan Agama Islam di SLB Pangkalpinang. Strategi guru dalam menyampaikan materi pembelajaran menjadi hal penting dan sangat diutamakan. Menurut Isnainy selaku guru PAI di SDLB Negeri Pangkalpinang mengatakan bahwa, strategi merupakan cara yang digunakan untuk membuat rencana pembelajaran sebelum pelaksanaan pembelajaran dengan mengaplikasikan berbagai metode dan alat peraga agar tercapai tujuan tertentu. Hal senada juga disampaikan oleh Ovi bahwa, strategi sangat diperlukan dalam proses belajar mengajar agar suatu kegiatan bisa berjalan dengan lancar. Dalam kegiatan belajar mengajar tidak hanya menggunakan satu strategi saja, tapi ada beberapa strategi yang digunakan dalam satu materi sehingga proses pembelajaran tidak membosankan peserta didik.

Berdasarkan analisa dari hasil wawancara, starategi merupakan suatu cara yang digunakan untuk mencapai hasil pembelajaran yang baik. Dengan menggunakan strategi yang tepat maka, bisa memberikan hasil yang maksimal dalam proses pembelajaran. Dengan adanya pemahaman guru tentang strategi pembelajaran, guru mampu menciptakan suasana belajar yang menyenangkan.

Melihat akan pentingnya strategi dalam pembelajaran, untuk itu guru dapat pertimbangan pemilihan strategi pembelajaran dan prinsip-prinsip strategi pembelajaran. Beberapa pertimbangan yang harus diperhatikan antara lain: (Sanjaya, 2010)

1) Pertimbangan yang berhubungan dengan tujuan yang ingin dicapai;

2) Pertimbangan yang berhubungan dengan bahan atau materi pembelajaran;

3) Pertimbangan dari sudut siswa.

Sedangkan prinsip-prinsip dalam penggunaan strategi Pembelajaran antara lain:

1. Berorientasi pada tujuan. Tujuan pembelajaran dapat menentukan suatu strategi yang harus digunakan guru. Untuk mencapai tujuan tersebut, siswa harus berpraktik secara langsung.

2. Aktivitas. Belajar bukanlah menghafal sejumlah fakta atau informasi. Akan tetapi berbuat memperoleh pengalaman tertentu sesuai dengan tujuan yang diharapkan. Karena itu, strategi pembelajaran harus dapat mendorong aktivitas siswa.

3. Individualitas. Mengajar adalah usaha mengembangkan setiap individu siswa, walaupun mengajar pada sekelompok siswa. Untuk itu, hakekat yang ingin dicapai adalah perubahan perilaku setiap siswa.

4. Integritas Mengajar harus dipandang sebagai usaha mengembangkan seluruh pribadi siswa. Mengajar bukan hanya mengembangkan kemampuan kognitif saja, akan tetapi juga meliputi aspek afektif dan psikomotorik. Untuk itu, strategi pembelajaran harus dapat mengembangkan seluruh aspek kepribadian siswa secara terintegrasi.

Berdasarkan analisa hasil wawancara, strategi pembelajaran yang digunakan oleh guru Pendidikan Agama Islam di SLB Pangkalpinang untuk anak berkebutuhan khusus (Tunagrahita Sedang) yakni: strategi Active Learning, strategi Contextual Teaching Learning (CTL), Cooperative Learning dan PAIKEM. Strategi ini pada umumnya, sering dilakukan oleh guru Pendidikan Agama Islam dalam proses pembelajaran untuk meningkatkan pemahaman materi, terlebih khusus bagi Anak Tunagrahita dengan kategori sedang.

\section{1) Strategi Active Learning}

Strategi Active Learning merupakan cara pandang yang menganggap belajar sebagai kegiatan membangun makna atau pengertian terhadap pengalaman dan informasi yang dilakukan oleh peserta didik, bukan guru (Hidayat 2016). Active learning juga dimaksudkan untuk menjaga perhatian peserta didik agar tetap mempunyai tujuan pada proses pembelajaran. Dalam strategi pembelajaran Active Learning itu sendiri peserta didik berusaha sungguh-sungguh mengambil tanggung jawab lebih besar pada cara belajarnya sendiri. (Wardhani, 2013) Untuk itu, Active Learning merupakan strategi yang bisa diaplikasikan dalam pembelajaran Anak Tunagrahita Sedang. 
Menyampaikan materi Pendidikan Agama Islam dengan strategi Active Learning bagi Anak Tunagrahita Sedang, Ovi melakukan beberapa tahapan yaitu: pertama pendekatan dengan mengenal karakter peserta didik, sehingga guru bisa mengelolah kelas dengan optimal dalam proses pembelajaran. Kedua, memahami materi yang akan disampaikan. Ketiga, menggunakan metode dan media apa yang cocok. Keempat memberikan hadiah untuk memacu semangat peserta didik aktif dalam belajar."

Hal senada juga dilakukan oleh Isnainy dalam proses pembelajaran dengan menggunakan strategi Active Learning bagi peserta didik Anak Tunagrahita Sedang dengan melakukan: pertama, mengkondisikan kelas dengan cara pendekatan, tujuannya untuk mengetahui kesiapan mereka dalam pelaksanaan pembelajaran. Kedua, memberikan arahan tentang materi yang akan disampaikan, kemudian memberikan pertanyaan. Ketiga, menggunakan media atau alat peraga dalam menunjang proses pembelajaran. Keempat, dalam penyampaian materi lebih sering menggunakan metode tanya jawab, agar mereka lebih aktif dalam proses pembelajaran.

Berdasarkan analisa dari hasil wawancara, tahapan yang dilakukan dalam pembelajaran bagi Anak Tunagrahita Sedang antara lain: Pertama, melakukan pendekatan untuk mengenal karakter peserta didik, Kedua, memberikan arahan tentang materi yang akan disampaikan. Ketiga, menggunakan metode yang tepat sesuai dengan materi yang disampaikan. Keempat, memberikan hadiah supaya peserta didik tertarik dan aktif dalam proses belajar mengajar. Dengan menggunakan strategi Active Learning diharapkan dapat mengajak peserta didik (Anak Tunagrahita Sedang) dapat memahami materi yang disampaikan oleh guru. Pemahaman bukan hanya sekedar mengetahui, akan tetapi juga dapat memanfaatkan bahan-bahan yang telah dipahami melalui penelitian, tanggapan, sikap, dan perubahan tingkah laku dalam belajar.

Tahapan dalam menyampaikan materi kepada Anak Tunagrahita Sedang dengan mengggunakan strategi Active Learning, yaitu: 1) Menjelaskan tentang materi yang akan di pelajari. 2) Membuat kelompok kecil dengan tujuan untuk memudahkan dalam pemberian tugas. 3) Penggunaan alat peraga atau media yang sesuai dengan materi yang akan disampaikan. 4) Memberikan pertanyaan kepada peserta didik sesuai dengan materi yang telah disampaikan. 5) Mengevalusi agar mengetahui apakah peserta didik memahami atau tidak dengan materi yang telah disampaikan.

Penggunaan metode yang tepat bagi Anak Tunagrahita Sedang yaitu, metode kelompok, diskusi dan bertanya dalam menyampaikan materi. Materi yang diberikan untuk setiap kelompok dibedakan, akan tetapi tetap saling berkesinambungan dengan materi yang akan diajarkan. Contohnya materi tentang sholat dan wudhu. Sebelum memulai pelajaran, guru melakukan interaksi kepada peserta didik supaya lebih aktif bertanya dan memberikan contoh terlebih dahulu. Kemudian guru sering mengulang penjelasan karena Anak Tunagrahita Sedang sulit mengingat dan mudah lupa apa yang disampaikan, didukung dengan menggunaan gambar dan poster tentang praktek sholat dan wudlu.

Menyampaikan materi kepada Anak Tunagrahita Sedang, guru memerlukan beberapa kali pertemuan antara 2 atau 3 kali pertemuan. Sesuai dengan RPP yang sudah dirancang, metode mempraktikkan dan mengulang materi sering dilakukan, untuk membantu mereka mengigat kembali materi yang telah disampaikan. Karena Anak Tunagrahita Sedang sulit dan lambat memahami materi terlalu banyak, apalagi berkenaan dengan teori. Oleh sebab itu, pendekatan individu lebih efektif digunakan, untuk mengetahui peserta didik yang belum memahami dan mengerti materi yang telah disampaikan.

Berdasarkan analisa dari hasil wawancara, kendala yang dihadapi guru, untuk mengajak peserta didik aktif dalam menerima materi pelajaran adalah: peserta didik kelelahan setelah berolahraga; keterbatasan media pembelajaran; selanjutnya kondisi peserta didik yang mengalami Tunagrahita Sedang dan juga memiliki ketunaan ganda. Untuk mengatasi masalah tersebut, maka para guru menggunakan pendekatan individual terhadap peserta didik. Bagi peserta didik yang kelelahan setelah berolah raga, terlebih dahulu mengajak mereka kemusholah untuk berwudhu dan mengajak melaksanakan sholat dhuha. Selanjutnya mengajak peserta didik masuk kelas, namun tidak langsung langsung memberikan materi pelajaran. Melainkan terlebih dahulu mengajak bermain game, untuk melatih kefokusan dan menceriakan suasana hati mereka.

\section{2) Strategi Contextual Teacing Learning (CTL)}

Contextual Teacing Learning atau biasa di sebut dengan strategi CTL merupakan strategi pembelajaran yang menekankan kepada proses keterlibatan siswa secara penuh untuk menemukan materi yang dipelajarinya dan menghubungkannya dengan situasi kehidupan nyata, sehingga siswa didorong untuk dapat menerapkannya dalam kehidupan mereka. (Manungsong, 2016). Konsep belajar dengan strategi ini, mengaitkan antara materi yang diajarkanya dengan situasi dunia nyata dan mendorong siswa membuat 
hubungan antara pengetahuan yang dimilikinya, kemudian menerapkan dalam kehidupan sehari-hari. Sehingga, peserta didik akan belajar dengan baik terkait dengan kegiatan yang sering dilakukan, atau peristiwa yang terjadi di sekelilingnya. Menurut Hargio proses pembelajaran ini menekankan pada daya pikir (Santoso, 2012).

Dalam strategi ini, kelas berfungsi sebagai tempat berdiskusi hasil temuan di lapangan. Untuk itu, keterlibatan siswa dituntut secara penuh dalam proses pembelajaran. Karena strategi CTL, bukan hanya sekedar mendengarkan dan mencatat, akan tetapi belajar adalah proses berpengalaman secara langsung.

Penggunakan Strategi CTL dalam proses pembelajaran, menurut Wina, ada tiga hal yang harus dipahami, yaitu: pertama, CTL menekankan kepada proses keterlibatan siswa untuk menemukan materi yang dipelajari dan menghubungkan dengan situasi kehidupan nyata. Sehingga orentasi dari pembelajaran pada proses pengalaman secara langsung. Kedua, CTL mendorong agar siswa dapat menemukan hubungan antara materi yang dipelajari dengan kehidupan nyata. Sehingga siswa dituntut dapat menangkap hubungan antara pengalaman belajar di sekolah dengan kehidupan nyata. Ketiga; CTL dapat mendorong siswa untuk dapat menerapkan dalam kehidupan, bukan hanya mengharapkan siswa dapat memahami materi yang dipelajari, akan tetapi bagaimana materi tersebut dapat mewarnai perilakunya dalam kehidupan sehari-hari. (Sanjaya, 2010).

Melihat penjelasan diatas maka, strategi Contextual Teacing Learning/CTL sangat cocok digunakan dalam meningkatkan pemahaman Anak Tunagrahita Sedang. Karena pada hakekatnya, proses pembelajaran Anak Tunagrahita Sedang lebih mudah dengan menggunakan praktik dibandingkan dengan teori. Dengan strategi ini, diharapkan dapat meningkatkan keingin tahuan tentang materi yang telah disampaikan serta dapat dilaksanakan dalam keseharian mereka baik di lingkungan keluarga, sekolah dan masyarakat. Penggunaan strategi ini sangat membantu Anak Tunagrahita Sedang dalam hal memahami materi, serta menjelaskan kembali isi materi yang telah disampaikan dan diaplikasikan dalam kehidupan sehari-hari.

Menurut Ovi, strategi CTL dapat digunakan dalam proses pendidikan Anak Tunagrahita Sedang. Menambahkan dan mengaitkan materi dengan kehidupan mereka, terlebih dahulu harus disesuaikan dengan materi yang akan disampaikan dengan kegiatan yang sering mereka lakukan. Untuk menunjang proses pembelajaran yang disampaikan agar mudah dipahami, maka penggunaan media seperti video atau mengambil contoh dari lingkungan peserta didik langsung sering digunakan. (salah satu contoh fungsi dan kegunaan musholah)".

Sebagaimana yang diungkapkan oleh Sumantri, tentunya guru memerlukan perhatian dan bimbingan yang ekstra terhadap peserta didik agar tujuan pembelajaran sesuai dengan apa yang diterapkan semula (Sumantri, 2016) Untuk itu, mengajar Anak Tunagrahita Sedang guru harus banyak berperan dengan melakukan pendekatan, memberikan motivasi serta banyak bercerita sehingga dalam proses pembelajaran, mereka bisa tenang dan terkendali. Karena asas dari penggunaan strategi CTL ini yaitu: membangun atau menyusun pengetahuan baru dalam struktur pengetahuan siswa berdasarkan pengalaman; proses pembelajaran didasarkan pada pencarian dan penemuan melalui proses berpikir secara sistematis dan model sebagai contoh untuk memperagakan yang akan ditiru; hakekat belajar adalah bertanya dan menjawab pertanyaan melaui konsep masyarakat belajar (Learning Community); kemudian dapat merefleksi kembali kejadian-kejadian atau peristiwa yang telah dilalui; selanjutnya dilakukan dengan penilaian yang bukan hanya melalui tes saja, akan tetapi melalui penilaian nyata yang terintegrasi dengan proses pembelajaran. Oleh sebab itu, penekanan diarahkan pada proses belajar bukan kepada hasil belajar.

Berdasarkan analisa hasil wawancara dengan guru PAI di SLB tersebut bahwa, mengajarkan materi kepada Anak Tunagrahita Sedang dengan menggunakan strategi CTL, memerlukan waktu yang panjang dalam proses memberikan pemahaman. Guru harus lebih pintar dan aktif dalam mengolah pertanyaan yang berkaitan dengan keseharian mereka dan menggunakan bahasa yang mudah dipahami. Guru memberikan kesempatan kepada peserta didik untuk menemukan atau menerapkan sendiri ide-ide yang telah mereka temukan, dan bisa menerapkan dalam keseharian mereka. Karena proses pembelajaran dengan menggunakan strategi CTL bukan menggunakan sistem hafalan dan sekedar mengumpulkan fakta yang lepas. Akan tetapi, belajar dengan cara proses pemecahan masalah melalui proses pengalaman sendiri dan hakikat dari hasil belajar dengan cara menangkap pengetahuan dari kenyataan.

\section{3) Strategi Cooperative Learning}

Cooperative Learning merupakan strategi penyelesaian tugas yang diberikan untuk siswa dengan cara berkelompok. Hal ini bisa dilakukan dengan penempatan anak dengan derajat kemampuan yang berbeda di 
dalam kelompok. Cooperative Learning juga dapat digunakan untuk pembelajaran lintas pelajaran dan kurikulum, serta untuk peserta didik dari berbagai tingkatan usia termasuk juga di dalamnya Anak Tunagrahita Sedang (Mahmud, 2014). Dalam kelompok tersebut, mempunyai latar belakang kemampuan akademik, jenis kelamin, ras, atau suku yang berbeda (heterogen). Sistem penilaian dilakukan terhadap kelompok. Setiap kelompok akan mendapatkan penghargaan (reward), jika kelompok mampu menunjukkan prestasi yang diisyaratkan.

Menurut Wina, ada empat unsur penting dalam penggunaan strategi Cooperative Learning, yaitu: 1) adanya peserta dalam kelompok, yaitu siswa yang melakukan proses pembelajaran dalam setiap kelompok belajar; 2) adanya aturan kelompok, yaitu adanya sesuatu yang menjadi kesepakatan semua pihak terlibat; 3) adanya upaya belajar setiap anggota kelompok, yaitu segala aktivitas siswa untuk meningkatkan kemampuan siswa; 4) adanya tujuan yang harus dicapai, yaitu untuk memberikan arah perencanaan, pelaksanaan, dan evaluasi. (Sanjaya, 2010).

Menurut Ovi dan Isnainy, upaya guru dalam menerapkan strategi Cooperative Learning ke dalam proses pembelajaran Anak Tunagahita Sedang, harus disesuikan dengan materi apa yang akan diajarkan. Pembagian kelompok dilakukan dengan tujuan agar dapat membagi peserta didik, baik dari segi kemampuan dan memahami materi. Sehingga peserta didik yang lebih mudah memahami materi yang disampaikan dapat membantu temannya yang lain. Strategi ini juga dapat menggunakan permainan game untuk menarik minat peserta didik.

Bentuk belajar kelompok menekankan adanya interaksi antara peserta didik dalam suatu kelompok. Interaksi membuat semua anggota kelompok belajar untuk saling bertatap muka, sehingga peserta didik dapat melakukan komunikasi baik dengan guru maupun dengan sesama teman kelompok. Interaksi ini diharapkan dapat memungkinkan peserta didik menjadi sumber belajar bagi sesamanya. Untuk itu Wina Sanjaya menyebutkan, prinsip-prinsip dalam menggunakan strategi Cooperative Learning dalam proses pembelajaran yaitu; a) Prinsip Ketergantungan Positif. b) Tanggung Jawab Perseorangan. c) Interaksi Tatap Muka. d) Partisipasi dan Komunikasi (Sanjaya, 2010).

Berdasarkan analisa hasil wawancara bahwa, menggunakan strategi Cooperative Learning dalam proses pembelajaran bagi Anak Tunagrahita Sedang, guru harus mengetahui kesesuaian materi dan strategi yang digunakan. Selanjutnya memudahkan guru dalam menyampaikan materi karena, ada pembagian kelompok. Namun, ada juga kendala yang dihadapi guru dengan menggunakan strategi ini, karena peserta didik susah diatur dan rasa manja yang berlebihan kepada guru. Kondisi ini membuat peserta didik sulit dikontrol dan suasana kelas akan menjadi ramai.

\section{4) Strategi PAIKEM}

Strategi PAIKEM merupakan pembelajaran bermakna yang dikembangkan dengan cara, membantu peserta didik membangun ketertarikan antara informasi pengetahuan yang baru dengan pengetahuan lain yang telah dimiliki dan dikuasai peserta didik. Peserta didik belajar bagaimana mereka mempelajari konsep dan bagaimana konsep tersebut dapat dipergunakan di luar kelas (Suprijono, 2009).

Penggunaan strategi PAIKEM dalam proses pembelajaran, tergantung materi apa yang akan disampaikan. Perkenaan dengan Anak Tunagrahita Sedang, maka guru harus melihat kondisi mereka. Pembelajaran di luar kelas akan dapat membantu mereka kreatif dan meningkatkan semangat dengan membuat pembelajaran menyenangkan. Adapun penataan ruangan yang tidak seperti biasanya membuat peserta didik tidak bosan dengan pengaturan kursi dan meja yang berubah-ubah disetiap pembelajaran.

Menurut Ovi, penggunaan strategi PAIKEM dalam proses pembelajaran jarang digunakan, karena harus melihat kesesuaian dengan materi yang akan disampaikan. Karena strategi ini juga harus didukung dengan penataan ruangan kelas, supaya peserta didik tidak bosan dalam kelas serta menggunaan media yang tepat. Sedangkan Isnayni menambahkan, penggunaan strategi PAIKEM lebih sering mengajak peserta didik untuk belajar di luar kelas dengan menyesuaikan dengan materi, terlebih dahulu menjelaskan terkait materi apa yang akan dibahas, (salah satu tentang manfaat pohon bagi kehidupan manusia).

Berdasarkan analisa hasil wawancara, penggunaa strategi PAIKEM jarang digunakan, karena bagi Anak Tunagrahita Sedang sulit menggunakan strategi yang bervariasi. Keterbatasan kondisi mereka dalam memahami penjelasan bahkan sebagain dari mereka baru belajar dengan mengenal huruf-huruf. Untuk itu, guru juga lebih banyak menggunakan praktik dari pada teori. Karena mereka bisa dilatih dan lebih mudah memahami penjelasan materi ketika diberikan contoh yang nyata, dibandingkan sebuah perumpamaan. Selanjutnya, dari keempat strategi yang telah dijelaskan di atas, strategi Active Learning dan strategi Contextual 
Teaching Learning (CTL) sering digunakan dalam proses pembelajaran bagi Anak Tunagrahita Sedang di SLB Pangkalpinang. Karena dua strategi ini bisa diaplikasikan untuk semua materi, sangat sederhana dalam penerapan dan pendekatannya.

\section{B. Kendala Guru PAI dalam proses pembelajaran bagi Anak Tunagrahita Sedang di SDLB Negeri Pangkalpinang}

Salah satu faktor yang mempengaruhi keberhasilan dalam proses pembelajaran adalah peran guru. Guru ditutut untuk mengembangkan materi pembelajaran dengan matode dan strategi pembelajaran. Namun dengan kondisi peserta didik yang berbeda (berkebutuhan khusus), menuntut guru lebih cerdas dalam menggunakan metode tersebut. Agar materi yang disampaikan bukan hanya sekedar dapat dimengerti akan tetapi bisa dipahami sehingga bisa diaplikasikan dalam kehidupan sehari-hari. Selanjutnya, guru diharapkan dapat memberikan layanan yang bersifat positif agar Anak Tunagrahita Sedang dapat menyesuaikan diri dengan teman sebayanya.

Selain kendala penggunaan strategi pembelajaran bagi Anak Tunagrahita Sedang yang dihadapi guru PAI di SLB Pangkalpinang, ada faktor lain yang menjadi kendala dalam memberikan dan meningkatkan pemahaman materi yang disampaikan. Berdasarkan analisa hasil wawancara dengan guru PAI di SLB Pangkalpinang, Faktor yang berpengaruhi kendala tersebut adalah:

\section{Faktor Internal}

Kendala yang dihadapi guru dalam memberikan pemahaman kepada peserta didik tunagrahita sedang dalam proses pembelajaran Pendidikan Agama Islam, yaitu:

Pertama, Profesionalitas seorang guru, dalam proses pembelajaran guru tidak membeda-bedakan dalam memberikan penjelasan dan pemahamann kepada peserta didik. Pendekatan individual lebih banyak dilakukan, interaksi antara peserta didik dan guru harus baik dalam memberikan penjelasan kepada mereka. Kedua, Kurangnya kesiapan dan mental guru, membuat proses pembelajaran kurang optimal. Ketiga, ketersediaan media atau alat peraga yang tidak sesuai dengan materi yang disampaikan membuat peserta didik tidak bersemangat. Keempat, keterbatasan guru dalam meggunakan bahasa yang mudah dipahami oleh Anak Tunagrahita Sedang dalam proses menjelaskan materi di kelas, sehingga anak sulit untuk menerima dan memahami materi yang disampaikan

\section{Faktor Eksternal}

Faktor eksternal adalah sesuatu yang berada di luar diri anak mengakibatkan anak menjadi memiliki hambatan perkembangan dan hambatan belajar, sehingga mereka memiliki kebutuhan layanan khusus dalam Pendidikan (Mais, 2016) Faktor eksternal menjadi kendala bagi guru dalam meningkatkan pemahaman Anak Tunagrahita sedang dalam proses pembelajaran Pendidikan Agama Islam. Faktor eksternal tersebut antara lain: pertama, Kondisi Anak Tunagrahita sedang yang memiliki kemampuan intelektual di bawah rata-rata. Kedua, peserta didik mudah bosan dan sering bermain-main, menyebabkan kondisi kelas kurang terkendali. Ketiga, kurangnya ketersediaan fasilitas dalam menunjang proses pembelajaran. Keempat, kurangnya ketersediaan buku penunjang pembelajaran khusus untuk Anak Tunagrahita sedang yang mengacu kepada kurikulum 2013.

\section{Kesimpulan}

Strategi pembelajaran yang digunakan oleh guru Pendidikan Agama Islam bagi Anak Tunagrahita Sedang di SLB Pangkalpinang yaitu: strategi Active Learning, strategi Contextual Teaching Learning (CTL), Cooperative Learning dan PAIKEM. Namun yang sering digunakan dalam proses pembelajaran adalah strategi Active Learning, dan strategi Contextual Teaching Learning (CTL). Penggunaan strategi pembelajaran yang baik dan sesuai dengan materi yang disampaikan, dapat membantu proses pembelajaran lebih baik.

Adapun kendala yang dihadapi guru Pendidikan Agama Islam dalam menyampaikan materi pembelajaran bagi Anak Tunagrahita Sedang dipengaruhi dari faktor internal dan faktor eksternal. Faktor internal yaitu: guru tidak membeda-bedakan dalam memberikan penjelasan dan pemahamann kepada peserta didik. Kedua, Kurangnya kesiapan dan mental guru, membuat proses pembelajaran kurang optimal. Ketiga, keterbatasan guru dalam meggunakan bahasa yang mudah di pahami oleh Anak Tunagrahita Sedang. Sedangkan faktor eksternalnya yaitu pertama, Kondisi Anak Tunagrahita Sedang yang memiliki 
kemampuan intelektual di bawah rata-rata. Kedua, peserta didik mudah bosan dan sering bermain-main, menyebabkan kondisi kelas kurang terkendali. Ketiga, kurangnya ketersediaan fasilitas dalam menunjang proses pembelajaran. Keempat, kurangnya ketersediaan buku penunjang pembelajaran khusus untuk Anak Tunagrahita yang mengacu kepada kurikulum 2013.

\section{Referensi}

Atmaja, Jati Rinakri. 2018. Pendidikan dan Bimbingan Anak Berkebutuhan Khusus. Bandung: PT Remaja Rosdakarya.

Daradjat, Zakiah. 2011. Ilmu Pendidikan Islam. Jakarta: Bumi Aksara.

Delphie, Bandi. 2006. Pembelajaran Anak Tunagrahita Suatu Pengantar dalam PendidikanInklusi. Bandung: PT Refika Aditama.

Efendi, Mohammad. 2005. Pengantar Psikopedagogik Anak Berkelainan. Malang: Bumi Aksara.

Hidayat, Isnu. 2019. 50 Strategi Pembelajaran Populer Kumpulan Lengkap Teori dan Aplikasi Pembelajaran Masa Kini. Yogyakarta: DIVA Press.

Mahfud, Rois. 2011. Al-Islam: Pendidikan Agama Islam. Jakarta: Erlangga.

Majid, Abdul. 2015. Strategi Pembelajaran. Bandung: PT. Remaja Rosdakarya.

Majid, Abdul. 2012. Belajar dan Pembelajaran Pendidikan Agama Islam. Bandung: Remaja Rosdakarya.

Mais, Asrorul, Media Pembelajaran Anak Berkebutuhan Khusus, (Jawa Timur: CV Pustaka Abadi, 2016), hlm. 14.

Mangunsong, Frieda. 2016. Psikologi dan Pndidikan Anak Berkebuthan Khusus. Depok: LPSP3 UI.

Moeleong, Lexy J. 2001. Metodolologi Penelitian Kualitatif. Bandung: PT Remaja Rosdakarya.

Murtie, Afin. 2016 cet-4. Ensiklopedi Anak Berkebutuhan Khusus. Jogjakarta: Redaksi Maxima.

Nata, Abuddin. 2011. Prespektif Islam tentang Strategi Pembelajaran. Jakarta: Kencana

Prastowo, Andi. 2011. Metode Penelitian KualitatifDalam PrespektifRancangan Penulisan. Yogyakarta: Ar-Ruzz Media.

Rohani, Ahmad. 2010. Pengelolaan Pengajaran (Sebuah Pengantar Menuju Guru Profesional). Jakarta: PT. Rineka Cipta.

Ronny, Kountor. 2009. Metode Penelitian Untuk Penulisan Skripsi dan Thesis. Jakarta: Buana Printing.

Rosmawati, Kemis dan Ati. 2013. Pendidikan Anak Berkebutuhan Khusus Tunagrahita. Jakarta: Luxima.

Santoso, Hargio. 2012. Cara Memahami \& Mendidik Anak Bekebutuhan Khusus. Yogyakarta: Gosyen Publising.

Smart, Aqila. 2010. Anak Cacat Bukan Kiamat, Metode Pembelajaran \& Terapi untuk Anak Berkebutuhan Khusus. Yogyakarta: Kata Hati.

Somantri, Sutjihati. 2007. Psikologi Anak Luar Biasa. Bandung: PT. Refika Aditama.

Sugiyono. 2015. Metode Penelitian Pendidikan Pendekatan Kuantitatif, Kualitatif, dan R\&D, Bandung: ALFABETA.

Sukmadinata, Nana Syaodih. 2012. Metode Penelitian Pendidikan. Bandung: PT Remaja Rosdakarya.

Sumantri, Mohamad Syarif. 2016. Strategi Pembelajaran Teori dan Praktik Di Tingkat Pendidikan Dasar. Jakarta: PT. Rajagrafindo Persada.

Suprayogo dan Tobroni, Imam. 2003. Metodologi Penelitian Sosial-Agama. Bandung: PT Remaja Rosdakarya.

Suprihatiningrum, Jamil. 2013. Strategi Pembelajaran Teori dan Aplikasi. Yogyakarta: Ar-Ruzz Media.

Suprijono, Agus. 2009. Cooperatif Learning Teori dan Aplikasi PAIKEM. Yogyakarta: Pustaka Belajar.

Surya, Sutan. 2006. Panduan Menulis Skripsi. Yogyakarta: Pustaka Pena.

Syah, Muhibbin. 2010. Psikologi Pendidkan. Bandung: PT Remaja Rosdakarya.

Tafsir, Ahmad. 2006. Metodologi Pengajaran Agama Islam. Bandung: PT Remaja Rosdakarya.

Taufiq, Ahmad dkk. 2011. Pendidikan Agama Islam. Surakarta: Yuma Pustaka bekerja sama dengan UPT MKU UNS.

Uno, Hamzah B. 2009. Model Pembelajaran: Menciptakan Proses Belajar Mengajar yang Kreatif dan Efektif. Jakarta: PT Bumi Aksara.

Wardani, 2013. Pengantar Pendidikan Anak Berkebutuhan Khusus. Banten: Universitas Terbuka.

Wina Sanjaya. 2006. Strategi Pembelajaran Berorientasi Standar Proses Pendidikan. Jakarta: Kencana Prenadamedia Group.

..2010, Strategi Pembelajaran Berorientasi Standar Proses Pendidikan, Jakarta: PERNADA MEDIA GROUP.

Zahrah, Abu. 1997. Usul Fiqh. Mesir: Dal Al-Fikr Al-Araby.

Zulfa, Umi. 2010. Strategi Pembelajaran. Yogyakarta: Cahaya Ilmu. 